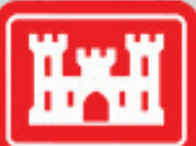

US Army Corps of Engineers

\title{
Vertical and Horizontal Datums Used in the Lower Mississippi Valley for US Army Corps of Engineers Projects
}

by Joseph B. Dunbar

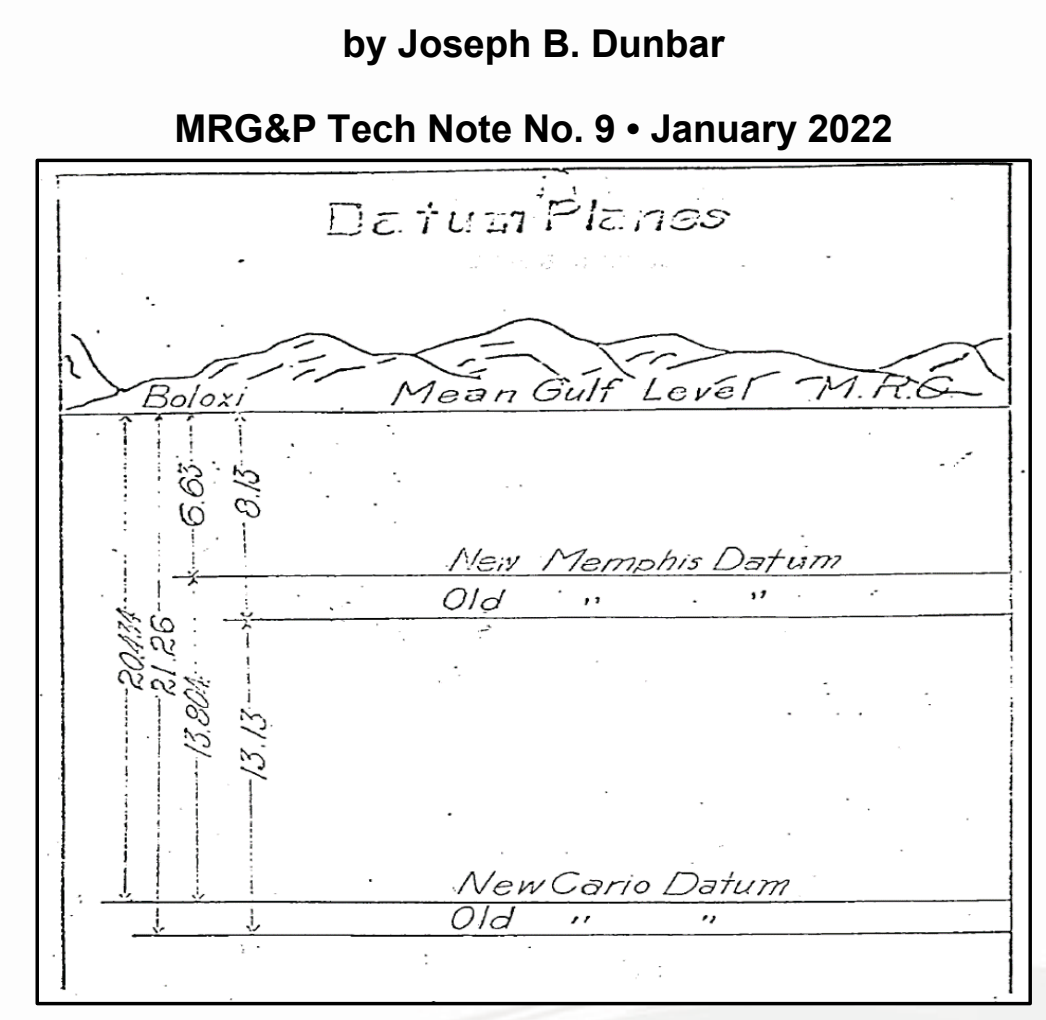

\section{$\mathrm{MRG \& P}$}

Mississippi River Geomorphology \& Potamology Program 


\section{MRG\&P \\ Mississippi River Geomorphology \& Potamology Program}

\section{INTRODUCTION}

Background. Six geodetic datums have been used by the US Army Corps of Engineers (USACE), Mississippi River Commission (MRC), for river surveys in the Lower Mississippi Valley (LMV). These legacy elevation datums are the Cairo datum, the Memphis datum, the Mean Gulf Level (MGL), the Mean Sea Level (MSL), the National Geodetic Vertical Datum (NGVD) 1929, and the North American Vertical Datum 1988 (NAVD88). The official geodetic datum currently prescribed by the USACE is NAVD88 (USACE 2010).

In addition to these different geodetic datums, hydraulic datums are in use by the USACE for rivers, lakes, and reservoir systems. Hydrographic surveys from the Mississippi River are typically based on a low water pool or discharge reference, such as a low water reference plane (LWRP), an average low water plane (ALWP), or a low water (LW) plane. The following technical note is intended to provide background information about legacy datums used in the LMV to permit comparison of historic maps, charts, and surveys pertaining to the Mississippi River in the LMV.

Purpose and Scope. The purpose of this report is to provide background information and history of different published horizontal and vertical datums used for presentation of hydrographic survey data from the Mississippi River. The goal is to facilitate understanding of differences with comparison to other historic surveys for change-detection studies along the river. Conversion values are identified herein for the earlier surveys where appropriate, and methods are presented here to evaluate the differences between earlier and later charts and maps. This report is solely intended to address the LMV area and historic surveys made there. This note is not applicable to areas outside of the LMV.

Throughout this technical note, historic hydrographic surveys and data from the Memphis, TN, to Rosedale, MS, reach will be used as examples of features of interest for discussion purposes. Selected historic hydrographic survey sheets at Helena, AR, are included as Plates 1 to 3 (Appendix C) of this document and will be used as examples for discussion purposes.

Important References. Information presented here was obtained from Elliott (1932), from an unpublished memo by the Vicksburg District ${ }^{1}$ on vertical control (Appendix A) and from the National Oceanic and Atmospheric Administration (NOAA 2014) website on datums (https://www.ngs.noaa.gov/). The unpublished memo on vertical control by the Vicksburg District is estimated to have been produced in 1949 and will subsequently be referenced herein as USACE (1949) for descriptive purposes. A copy of this memo is included in this technical note as Appendix A for wider dissemination of legacy documents that are difficult to obtain for those interested in information concerning early MRC map data and surveys in the Vicksburg District.

\footnotetext{
${ }^{1}$ USACE (US Army Corps of Engineers). 1949. Vertical Control. Unpublished memo. Vicksburg, MS: US Army Corps of Engineers, Vicksburg District.
} 


\section{MRG\&P}

Mississippi River Geomorphology \& Potamology Program

\section{VERTICAL DATUM}

Introduction. Three legacy elevation datums were used by the MRC prior to 1930 for surveys made on the Mississippi River. These legacy datums are identified as the Cairo datum, the Memphis datum, and the MGL (Figure 1). Vertical differences for these three datums are identified in Figure 1, and their relationship to MGL is further summarized below.

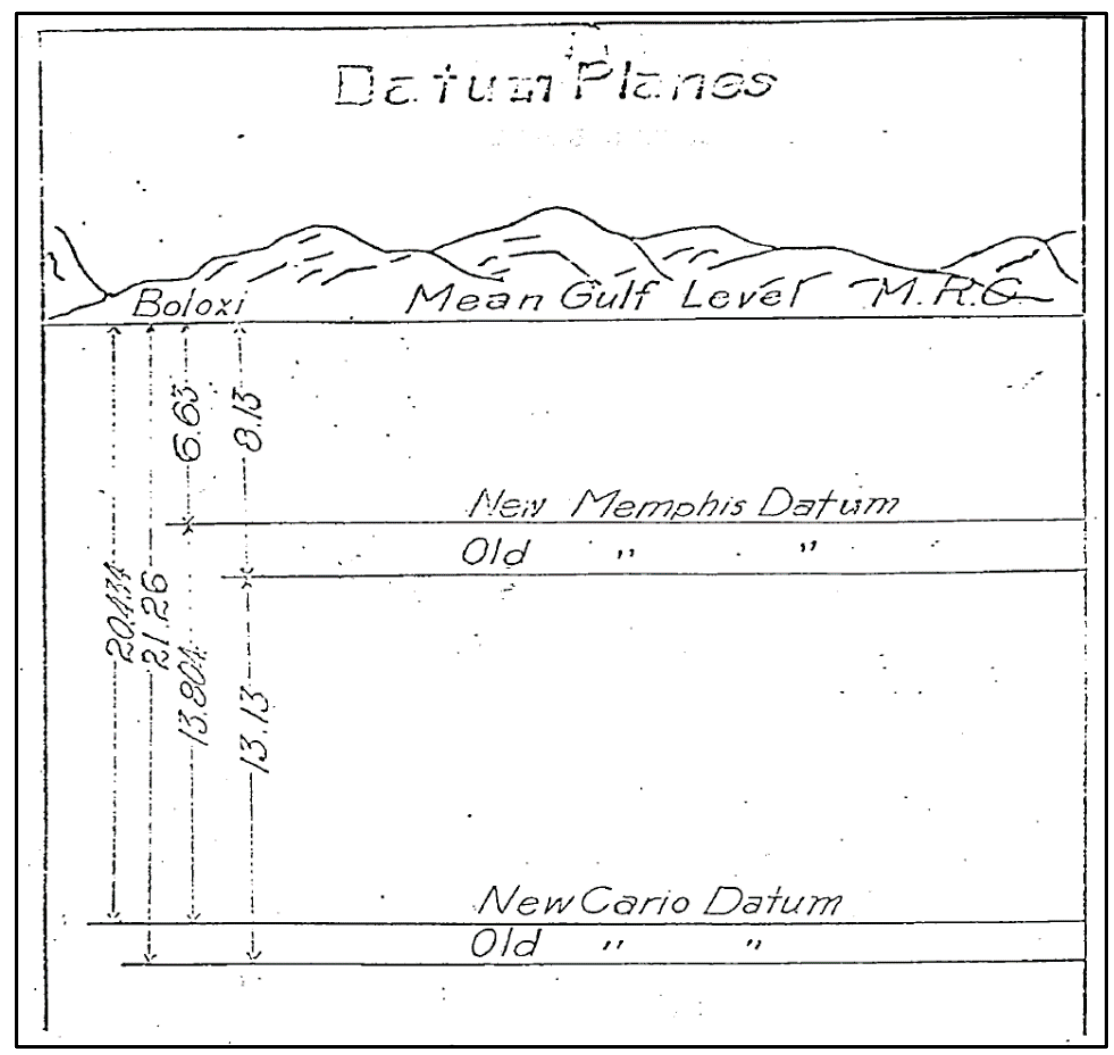

Figure 1. Historic datum planes used by the MRC in the LMV before 1929 (USACE 1949). Biloxi, MS, is identified as "Boloxi."

Cairo and Memphis Datums. Prior to the MRC being established in 1879, an assumed vertical datum was established at Cairo, IL, in 1876 by Brevet Brigadier (BG) General Cyrus. B. Comstock, USACE, in charge of field surveys at Cairo for the US Lake Survey. BG Comstock would later become President of the MRC for two different periods: from 1882 to 1884 and again from 1888 to 1895 (Camillo and Pearcy 2004). During the Civil War, he was on General US Grant's staff and was his senior secretary. After the war, he was superintending engineer of the geodetic survey in charge of the Northern and Northwestern Lakes and later for the progress of the Eads jetties at the mouth of the Mississippi River (Camillo and Pearcy 2004).

When the Cairo datum was established by BG Comstock, there was no connection by survey lines between Cairo and the Gulf of Mexico to accurately fix the elevation between these two points. 


\section{MRG\&P}

\section{Mississippi River Geomorphology \& Potamology Program}

The Cairo datum was based on the mean low water on the Cairo gauge of $9.16 \mathrm{ft},{ }^{1,2}$ and an arbitrary plane was established $300 \mathrm{ft}$ below this water level. This datum would serve as a temporary vertical reference for many years before accurate elevation control was established and this datum was abandoned.

BG Comstock in 1877 established a similar datum at Memphis, TN, as no direct level connection existed between Cairo and Memphis. The Memphis Datum was arbitrarily set at $225 \mathrm{ft}$ below the high water mark of 23 June 1858, with a gauge reading of $34.16 \mathrm{ft}$ on the Memphis gauge. A precise level survey was completed by 1880 between Memphis and Cairo, and the Cairo datum was fixed at $13.3 \mathrm{ft}$ below the Memphis datum.

Hydrographic surveys were made on the Mississippi River in 1879-80 and 1913-15 in the LMV that incorporated and/or referenced the Cairo and Memphis datums. Example survey sheets from Helena, AR, are used here for illustration purposes for survey information contained and presentation of the Memphis datum reference (see Plates 1 and 2 [Appendix C]). The portion of the survey sheet describing the elevation datum is presented in Figures 2 and 3 for the 1879-80 and 1913-15 surveys, respectively.

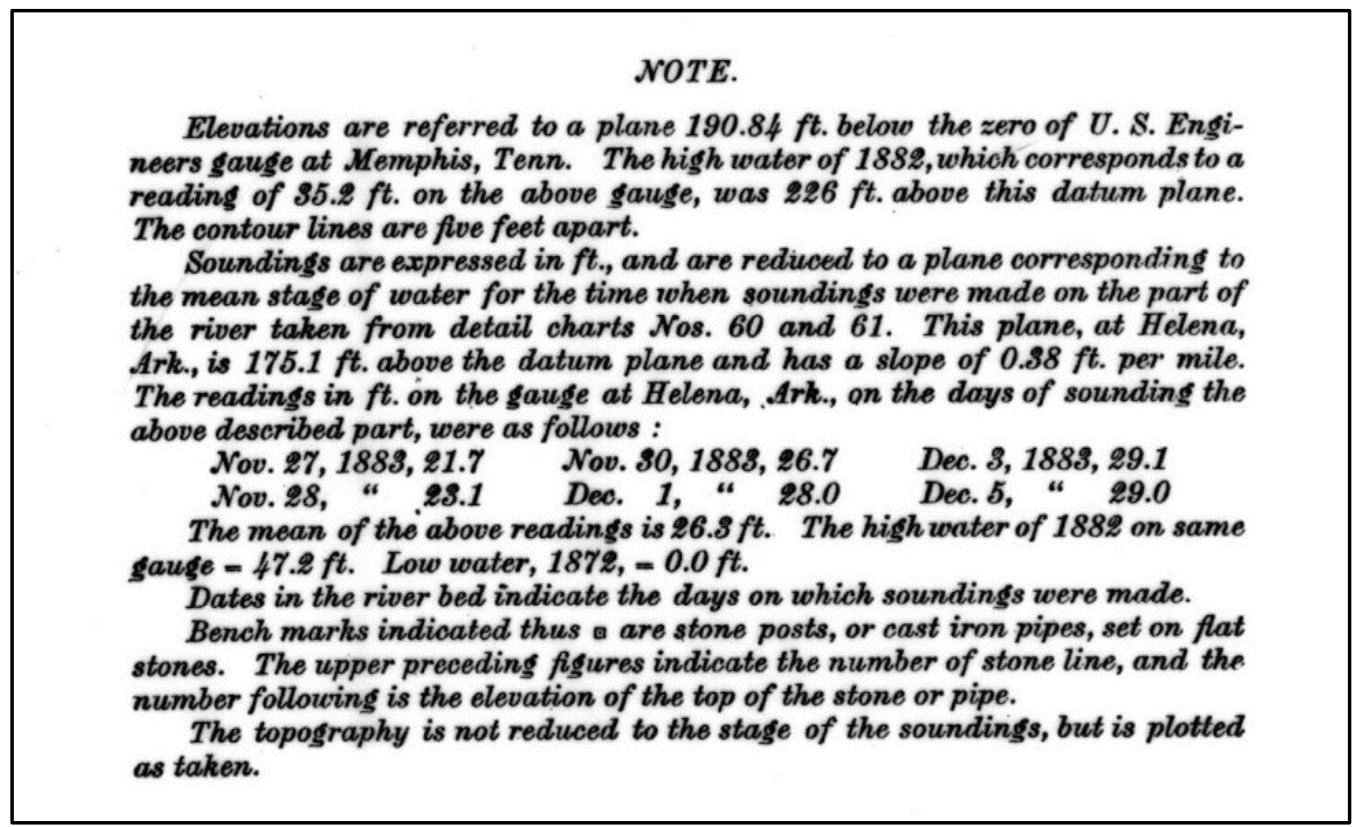

Figure 2. Elevation note from 1879-1880 survey from Helena, AR, chart No. 27 (MRC 1880).

\footnotetext{
${ }^{1}$ For a full list of the spelled-out forms of the units of measure used in this document, please refer to US Government Publishing Office Style Manual, 31st ed. (Washington, DC: US Government Publishing Office 2016), 248-52, https://www.govinfo.gov/content/pkg/GPO-STYLEMANUAL-2016/pdf/GPO-STYLEMANUAL-2016.pdf.

${ }^{2}$ For a full list of the unit conversions used in this document, please refer to US Government Publishing Office Style Manual, 31st ed. (Washington, DC: US Government Publishing Office 2016), 345-7, https://www.govinfo.gov/content/pkg/GPO-STYLEMANUAL-2016/pdf/GPO-STYLEMANUAL-2016.pdf.
} 
NOTES.

Elevations are given in feet above the Memphis datum plane which is 190.84 feet below the zero of the $\boldsymbol{U}$. S. Engineer gage at Memphis, Tenn., and 6.63 feet below mean Gulf level at Biloxi, .Miss.

The contour lines are five foet apart. The elevations of the contoury above the Memphis datum are indicated by figures which are placed on the higher side of the lines to shou the direction of the slopes. The elevations of the river bank above the datum are also shown.

Triangulation stations are represented thus $\Delta$

Precise level benchmarks are represented thus 0

Ordinary level benchmarks are represented thus a

Leves represcnted thus have this cross section

Levees represented thus have this cross section

The shore line is not reduced to the stage of the soundings but is platted as surreyed. The dates shoun inlicate the days on which soundings were made.

Soundings are expressed in feet and are reduced to the mean stage of uater on the days when the depths on this chart were measured. This stage at top of chart is 153.71 feet and at Helena, .Ark., C. S. Engr. sage 151.5' feet above the datum, and. has an areruge slope of 0.31 foot per nile.

The readings, in feet. on the U. S. Engineer guge at Helena, Ark., on the days of sounding were us follows:

$$
\text { Sept. 30, 1913, 3.2 Oct. 1, 1913, 3.0 Oct. 2, 1913, 2.7 }
$$

The mean of the abore readings is s.o feet.

The ligh uriter of 1913 on the Helena gage urs 55.20 feet $=203.64$ feet above the latum, and the low water of 1895 on the same gage uxts -3.00 feet $=140.44$ feet aboce the iatum.

Figure 3. Elevation note from 1913-15 survey from Helena chart No. 26 (MRC 1915).

Based on information presented in Figure 1, conversion of the older Memphis datum to MGL is accomplished by subtracting a value of $6.63 \mathrm{ft}$ from the posted elevation values in Plates 1 and 2 (Appendix C) (USACE 1949). Further description and conversion of these datums to MGL is continued.

Mean Gulf Level (MGL). MGL was the first sea level datum established for the Mississippi Valley. The MRC in 1881 established a tide gauge station at Biloxi, MS, with a preliminary value of MGL based on the average of readings between 28 May to 13 October 1882. A precise level survey was eventually made in 1882 between Carrollton, LA, and Biloxi, MS, which made possible the connection of the Cairo and Memphis datums to MGL (Elliott 1932; USACE 1949). The Memphis datum was found to be $8.13 \mathrm{ft}$ below MGL. This average value was used until 1899 when a new MGL value was established, based on a longer, $5 \mathrm{yr}$ record of sea level readings.

Both the Cairo and the Memphis level lines were subsequently rerun and adjusted to obtain a new value for MGL in 1899. The Cairo datum was set at $20.434 \mathrm{ft}$ below MGL, and the Memphis datum was set at $6.630 \mathrm{ft}$ below MGL (Figure 1). The MRC officially established the new value for MGL on 21 June 1899. Some of the post-1927 Flood control engineering was constructed using this elevation base (Elliott 1932). MGL was made obsolete for a USACE datum except for historical studies in 1941, and there is no single equation that may be applicable to convert MGL to MSL (USACE 1949).

Mean Sea Level (MSL). Establishing a network of elevation benchmarks along the Mississippi River was an ongoing effort by the MRC to establish vertical control along the river corridor. The MRC published in three volumes in 1915, Permanent Marks, Survey of the Mississippi River from Cairo to the Gulf of Mexico, the benchmark descriptions used to establish vertical control in the LMV (USACE 1949). At this time, copies of the three-volume set 


\section{MRG\&P \\ Mississippi River Geomorphology \& Potamology Program}

from 1915 are presently unavailable for examination and study. The ERDC library has not been able to locate a complete set of these volumes. To date, only a single copy of Volume 1 (MRC 1929) has been found at the MRC headquarters, which corresponds to the reach of river from Cairo, IL, to the mouth of the Arkansas River. Benchmark data from 1915 and elevation in Memphis Datum are presented on the hydrographic survey sheets published in 1915.

The US Coast and Geodetic Survey (USCGS) in 1912 standardized and adjusted all benchmark elevations in the LMV (USACE 1949). This adjustment was based on results of additional level surveys and compilation of all the known benchmarks by the USACE, the MRC, the Missouri River Commission, and other government agencies (USCGS 1914). Elevations based on this adjustment were published by the USCGS (1914) and by the US Geological Survey (USGS) for the respective states involved (USGS 1916a, 1916b, 1916c). An MSL datum was established formally in 1929.

In terms of vertical control, the number of tide station benchmarks and the length of precise level lines were increased across the United States during the early 1900s by the USCGS (Zilkoski and Young 1985). It grew from five tide gauges in the network in 1900 (Boston, MA; Sandy Hook, NJ; Washington, DC; New York, NY; and Biloxi, MS) to eight in 1903 and nine stations by 1912.

This increase also involved vertical adjustments to benchmarks in the network as the leveling lines increased, with a total of $31,789 \mathrm{~km}$ in $1903 ; 38,359 \mathrm{~km}$ in 1907 ; and $46,462 \mathrm{~km}$ in 1912 . An important network adjustment of the vertical control occurred in 1929 with the addition of the Canadian network. Together, the two networks accounted for nearly 107,000 geodetic quality level lines and comprised 21 tide stations in the United States and 5 in Canada (Zilkoski and Young 1985). This network of 26 stations in North America established the Sea Level Datum of 1929 and the concept of MSL.

The 1912 and 1929 General Adjustment by the USCG established local MSL at the various tide stations at the $0 \mathrm{ft}$ elevation. The datum was defined by the observed heights of MSL at 12 (1912) and then 26 (1929) tide gauges and by the set of elevations of all benchmarks resulting from the 1929 adjustment. It was recognized then that these tide stations could not be on the same equipotential surface because of local effects involving sea surface topography, currents, water temperature, salinity, barometric pressure, and geological influences (gravity, uplift, subsidence, etc.) (Zilkoski and Young 1985).

However, it was believed at this time that the differences were minor and on the order of those observed from terrestrial level errors. In reality, the magnitude of the difference was estimated to be as much as $0.7 \mathrm{~m}$ from coast to coast. Consequently, a change in terminology occurred in May 1973 with Sea Level Datum of 1929 being renamed to the National Geodetic Vertical Datum 1929 (Federal Register 1973). This datum was not MSL and was not based on a geoid model or any other equipotential surface. Therefore, it was renamed NGVD29 to reflect the legacy of points and elevations expressed by this datum.

During the period from 1934 to 1939, a significant amount of first- and second-order leveling was run by the USACE and the USCGS. Much of this work could not be fitted within allowable error limits, and at the request of the MRC, a supplementary adjustment of the entire alluvial valley region was made in 1941 by the USCGS (USACE 1949). The 


\section{MRG\&P}

Mississippi River Geomorphology \& Potamology Program

difference between the 1929 and 1941 adjustments was negligible, and the question of vertical datum in this region was thought to have been settled for all time (USACE 1949).

North American Vertical Datum of 1988 (NAVD88). A new vertical datum control was established in 1991 with the next adjustment and inclusion of the Canadian, Mexican, and United States leveling observations. This datum consists of a leveling network across the North American continent, ranging from Alaska, through Canada, and throughout the continental United States, and consists of an additional $625,000 \mathrm{~km}$ of leveling surveys after 1929 (https://www.ngs.noaa.gov/datums/vertical/north-american-vertical-datum-1988.shtml).

Distortions amounting to as much as $9 \mathrm{~m}$ were observed to bring the new leveling to fit older NGVD29 height values. This datum is referenced to a point in Pointe-au-Pere, Rimouski, Quebec, Canada. Additional information about this datum will be described in a later section of this technical note, but information on horizontal datums will be described next.

\section{HORIZONTAL DATUMS}

Mississippi River Commission Datum. The subject of legacy datums is further continued with examination of horizontal control in the LMV and the use of the MRC datum. In the period 1905 to 1910, the MRC established a network of third-order triangulation stations along the Mississippi River based on astronomical observations at Memphis, TN, and Natchez, MS (USACE 1949). Early hydrographic surveys and maps by the MRC are based on the results of this triangulation. The USCGS in 1929 established a network of first-order triangulation stations in the Mississippi River Valley, making available a reference to the 1927 North American Datum (NAD27).

In the Vicksburg District, the horizontal difference between the MRC and NAD27 amounts to between 74 to $84 \mathrm{ft}$ in latitude and 3 to $15 \mathrm{ft}$ in longitude, with the MRC datum being north and west of the NAD27 position (USACE 1949). Registration marks for the MRC datum were generally included on all published hydrographic surveys though 1973-75 in the Memphis District (Plate 3 [Appendix C]). Horizontal position after 1941 was based on NAD27 (USACE 1949).

United States Standard Datum (USSD) and North American Datum (NAD). A national horizontal datum was established for horizontal location and position control in North America in 1901. This datum was established by the USCGS as a national horizontal datum for the United States and was initially known as the United States Standard Datum (USSD). The NAD was next created and adopted in 1913 when Canada and Mexico implemented the USSD, which was based on the Clarke's spheroid model of 1866 . This datum was based on classical surveying methods for locating points on the earth's surface.

The NAD was revised in 1927 as more survey data became available and errors were discovered. The 1927 revision involved the same spheroid and origin as the USSD datum. NAD1927, or NAD27, is based on a central point at Meades Ranch Triangulation Station (39 $13^{\prime} 26.686^{\prime \prime}$ north latitude, 98 32’30.506" west longitude), Kansas, from which all the latitude and longitude coordinate pairs in the United States are derived. This point is at the approximate geographic center of the United States, near the 39th north parallel and the 98th west 


\section{MRG\&P}

Mississippi River Geomorphology \& Potamology Program

meridian. Topographic maps published by the USGS after 1927 used this horizontal datum for presentation of topographic, cultural, and hydrologic features.

Most of the legacy structures built by the USACE used this datum for their horizontal position control outside of the LMV. As noted above, the MRC datum was routinely used in the LMV until approximately 1941 and was eventually replaced with NAD27.

North American Datum 1983 (NAD1983 or NAD83). NAD1983, or NAD83, is a spheroidbased datum that has replaced the older, legacy NAD27 datum. The establishment of this datum is based on advances in electronics and digital survey capabilities, satellite-based or Global Positioning System capabilities, interferometry of fixed points through time, and gravimetric considerations, with the origin of the datum at the earth's center of mass, as compared to a point on the earth's surface, previously used in the legacy NAD27 datum. This datum is based on the 1980 Geodetic Reference System spheroid model. There are measurable differences in distance between the legacy NAD27 and the newer NAD83 coordinate pairs. The NAD83 datum is nearly identical to the World Geodetic System 1984 spheroid datum. Adjustments have been made to the datum since its adoption, which are generally reflective by the year of their update (i.e., NAD83 [2011]).

\section{COMPARISON OF HISTORIC VERTICAL DATUMS IN THE LOWER MISSISSIPPI VALLEY (LMV)}

Introduction. Comparison of historic surveys for detecting horizontal change and for evaluating river channel deepening or shallowing through time requires knowledge of the survey characteristics and the vertical datums used. Factors involved in any comparison involve both horizontal position, typically the differences between NAD27 and NAD83, and vertical control with the two primary elevation datums being NGVD29 and NAVD83.

Geographic Information System (GIS) Software. Modern Geographic Information System (GIS) software fortunately recognizes the different legacy horizontal datums and makes registration of different maps, photography, and images a relatively simple process. The Environmental Systems Research Institute (ESRI) ArcGIS software, a common software in use by the USACE, makes georeferencing and coordinate transformation of different horizontal datums an easy process for overlaying and comparison of historic charts, maps, and surveys. Different datums are easily georeferenced to one another by identifying the projection property parameters for each map and chart layer for performing spatial analysis. An important feature contained on historic hydrographic surveys shown in Plates 1 through 3 (Appendix C) are the legacy benchmarks that are displayed for the respective river surveys shown on these plates.

Online Resources for Benchmark Elevation Data. The NOAA has an online resource for obtaining elevation data from benchmarks in the LMV with both NAVD88 and NGVD29 elevations, providing the benchmark is not recent. Recent benchmarks do not show the NGVD elevation as this datum is obsolete and no longer supported (the interactive NOAA (2020) website is at https://geodesy.noaa.gov/NGSDataExplorer/). Additionally, NOAA has available for download at this site statewide ESRI shapefiles of the known benchmarks and a Vertical Datum Transformation tool to convert between the two different datums. Selected examples are described here next. 


\section{MRG\&P \\ Mississippi River Geomorphology \& Potamology Program}

An example benchmark is presented in Figure 4 at Rosedale, MS, for DK0799 using the interactive NOAA website. The online datasheet for this benchmark is included in Appendix B. The datasheet identifies the NAVD88 elevation as being $148.27 \mathrm{ft}$ and the NGVD29 elevation as $148.49 \mathrm{ft}$, with a net difference of $0.22 \mathrm{ft}$ between the two values.

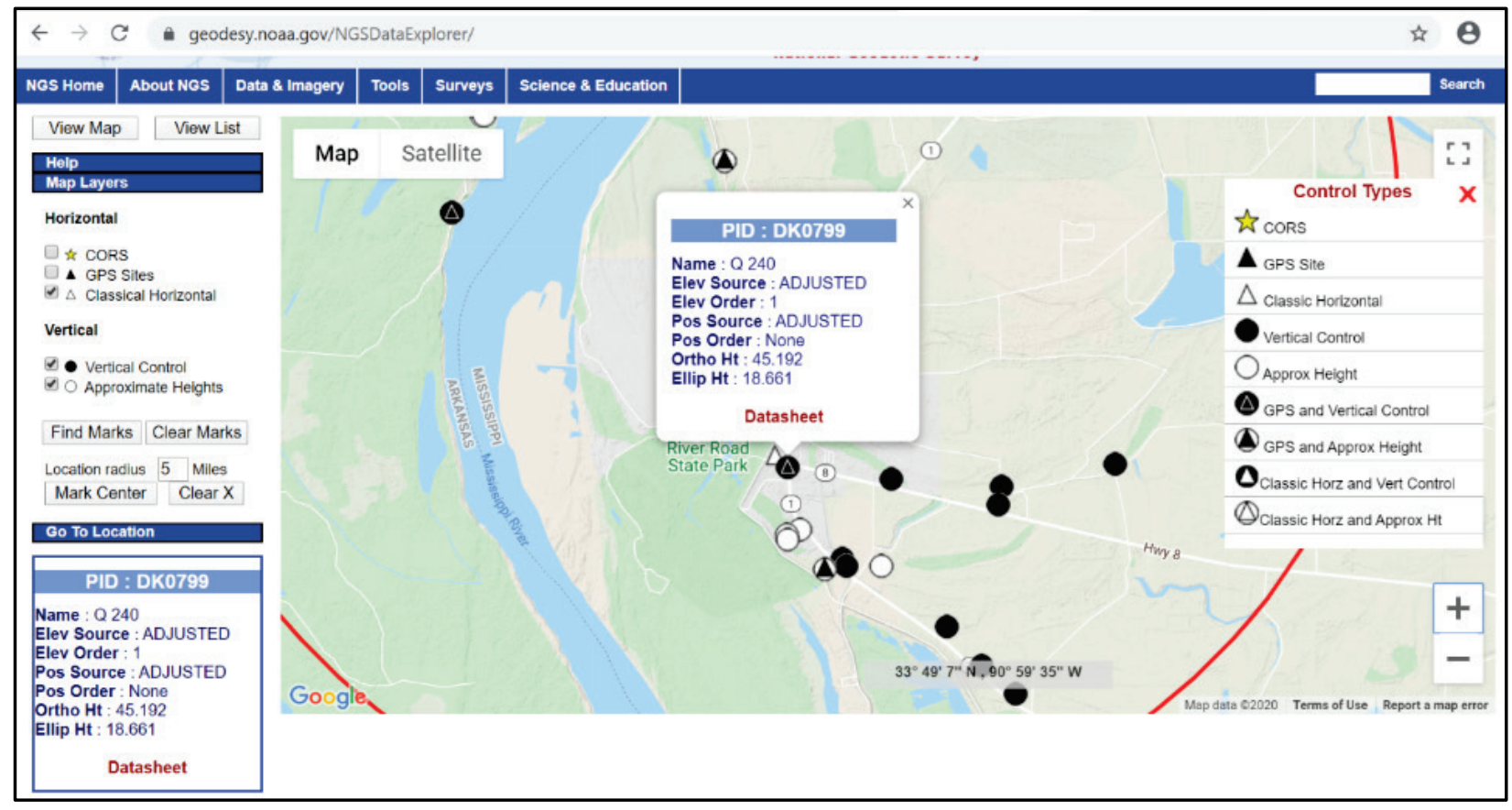

Figure 4. Benchmark data in the LMV from NOAA website with benchmark DK0799 and link to datasheet for obtaining elevation data and characteristics. This benchmark contains elevations in both NGVD29 and NAVD88.

Another benchmark, A305, is presented in Figure 5 from Helena, AR, and uses the downloadable statewide ESRI ArcView shapefile of benchmarks from the NOAA website. Contained in the attribute table for the benchmarks are links to the individual datasheets, (see example datasheet for A305 in Appendix B). The difference in elevation for this benchmark between NAVD88 (elevation $190.28 \mathrm{ft}$ ) and NGVD29 (elevation $190.59 \mathrm{ft}$ ) is $0.31 \mathrm{ft}$. 


\section{MRG\&P \\ Mississippi River Geomorphology \& Potamology Program}

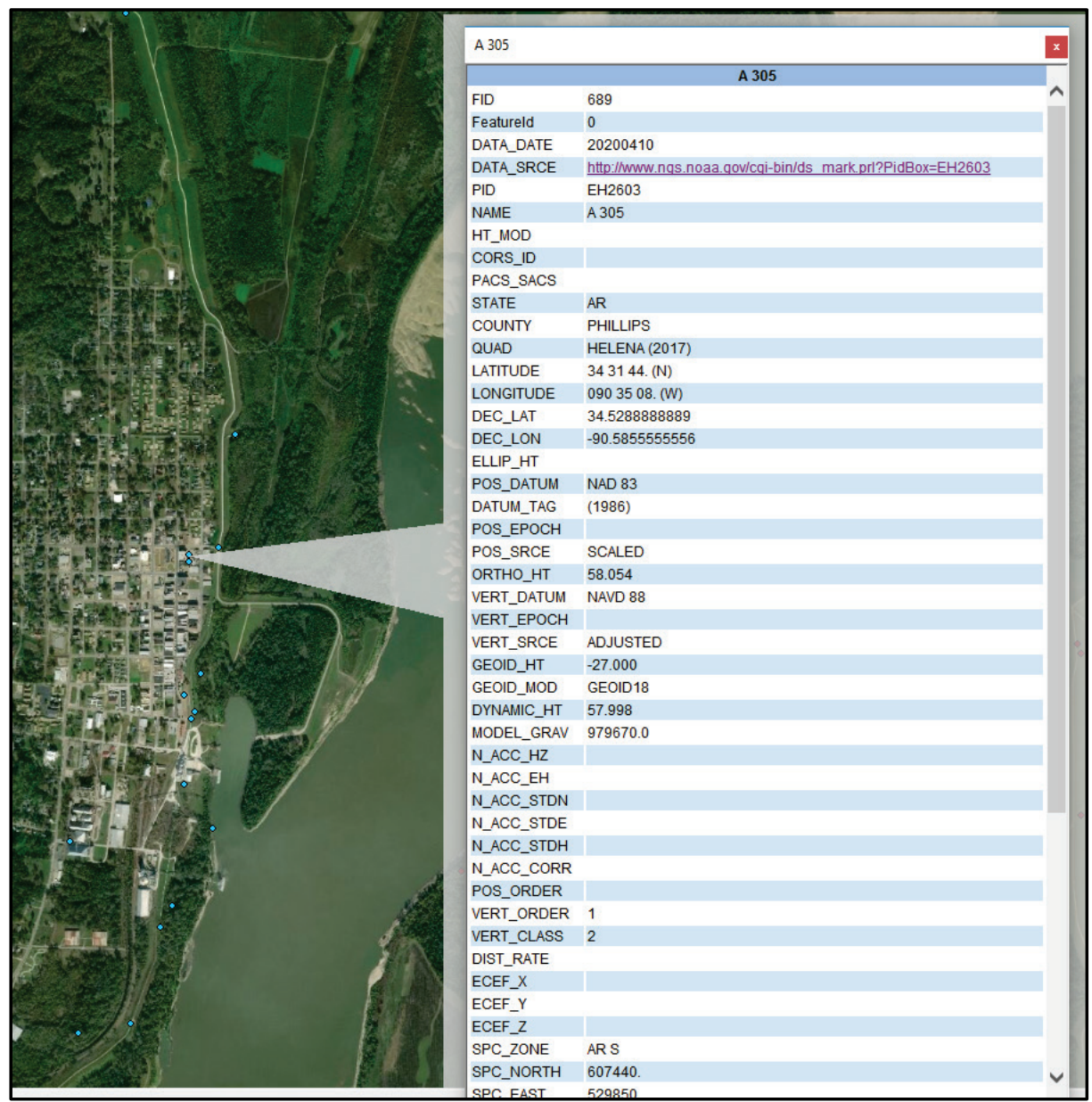

Figure 5. Benchmark A305 (PID EJ2603) at Helena, AR, identified as being from 1931 with NGVD29 and NAVD88 elevations (see datasheet A305 in Appendix B).

The third method to convert between vertical datums is to download the Vertical Datum Transformation tool from the NOAA (2014) website at https://vdatum.noaa.gov/. This tool permits conversion between NAD1927 and NAD83 and conversion of elevation values between NGVD29 and NAVD88 (Figure 6).

USACE has a similar datum transformation tool called Corpscon for datum conversion. The software tool is available for download at https://www.agc.army.mil/What-we-do/Corpscon/. This tool permits transformation of both horizontal and vertical datums previously described (Figure 6) (USACE 2004). 
Mississippi River Geomorphology \& Potamology Program
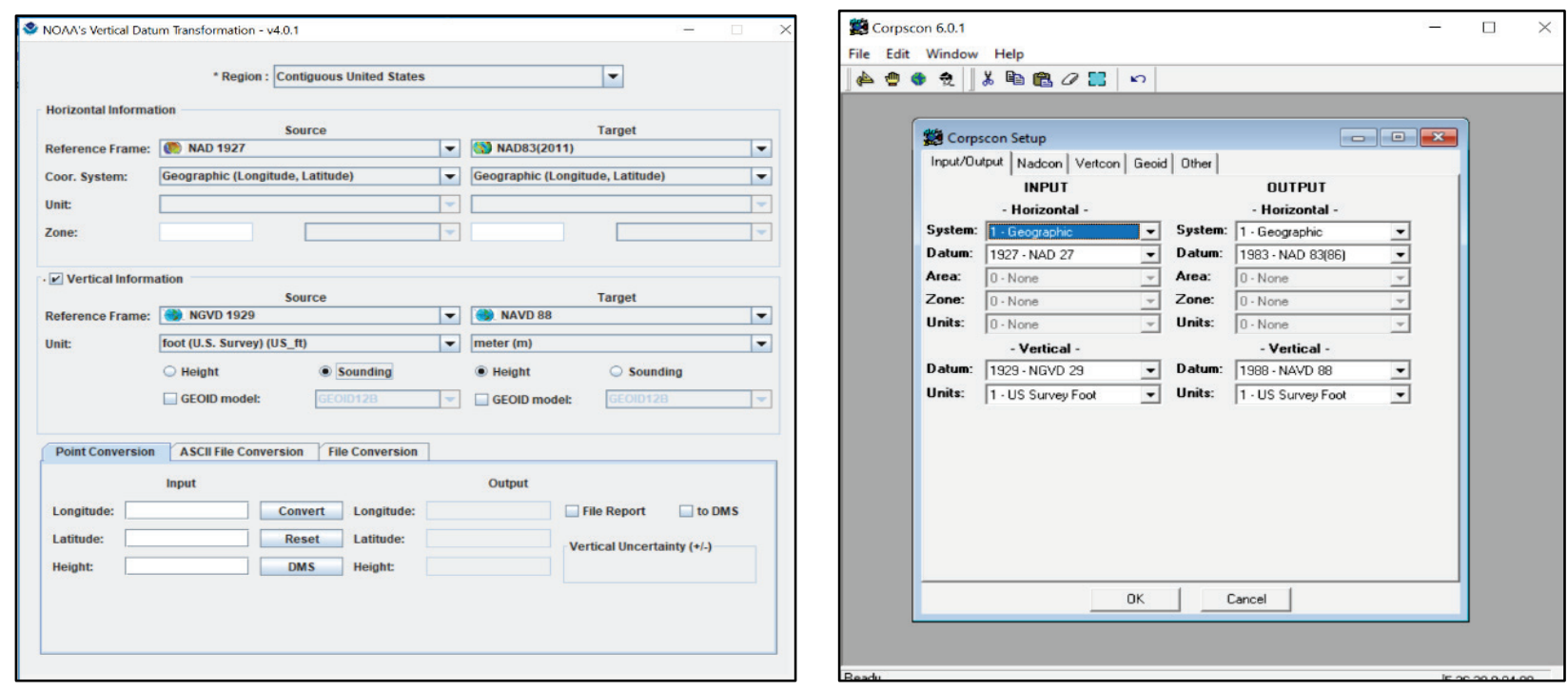

Figure 6. Vertical Datum Transformation tool (left) (NOAA 2014) and Corpscon tool (USACE 2004) (right).

\section{HYDRAULIC DATUMS}

Low Water Reference Plane (LWRP). The LWRP is the low water slope that is represented by a $97 \%$ exceedance discharge based on an observed period of record (Minyard 2007). Changes have occurred in the reference plane along with its period of record as identified by Table 1 for selected hydrographic surveys in the Memphis, TN, to Rosedale, MS, reach ${ }^{1}$. The plane has been adjusted periodically because of changes to historic stage trends observed for the river.

Systematic changes in the LWRP are generally related to natural and man-made activities in the watershed - including historic channel scouring, aggradation, regional and local subsidence, and uplift - or to a large influx of caving bank sediment from historic earthquake activity (i.e., New Madrid Earthquakes of 1811-1812). Mississippi River reaches that have experienced measurable changes in the LWRP through time are identified by Biedenharn et al. (2017). Both natural and manmade changes in the watershed have impacted the river differently along its longitudinal profile.

\footnotetext{
${ }^{1}$ Dunbar, J. B. 2020. Unpublished draft report. Geology, Geomorphology, and River Engineering in the Memphis to Rosedale Reach, Lower Mississippi River. Mississippi River Geomorphology and Potamology (MRG\&P) Program. Vicksburg, MS: US Army Engineer Research and Development Center.
} 


\section{MRG\&P}

Mississippi River Geomorphology \& Potamology Program

Table 1. Comparison of horizontal and vertical datum and water level reference for historic hydrographic surveys in the Memphis, TN, to Rosedale, MS, reach (USACE 1951, 1964, 1976, 1990). Surveys starting after 2000 are digital with no legacy published reference.

\begin{tabular}{|l|l|l|l|l|l||}
\hline Paper/Digital & $\begin{array}{l}\text { Year } \\
\text { Published }\end{array}$ & Survey Year & $\begin{array}{l}\text { Horzontal. } \\
\text { Datum }\end{array}$ & $\begin{array}{l}\text { Vertial } \\
\text { Datum }\end{array}$ & LWRP Reference \\
\hline $\begin{array}{l}\text { Memphis } \\
\text { Paper }\end{array}$ & 1951 & $1948-49$ & NAD & $\begin{array}{l}\text { ft, MSL } \\
\text { NGVD29 }\end{array}$ & 1948-49 LWRP \\
\hline $\begin{array}{l}\text { Memphis } \\
\text { Paper }\end{array}$ & 1964 & $1961-63$ & 1927 NAD & $\begin{array}{l}\text { ft, MSL } \\
\text { NGVD29 }\end{array}$ & $\begin{array}{l}\text { 1962 ALWP (20 yr low } \\
\text { water avg, 1942 to } \\
1961)\end{array}$ \\
\hline $\begin{array}{l}\text { Memphis } \\
\text { Paper }\end{array}$ & 1976 & $1973-75$ & 1927 NAD & $\begin{array}{l}\mathrm{ft}, \mathrm{MSL} \\
\text { NGVD29 }\end{array}$ & $\begin{array}{l}\text { 1974 LWRP (97\% } \\
\text { duration discharge } \\
\text { 1954-73) }\end{array}$ \\
\hline $\begin{array}{l}\text { Memphis } \\
\text { Paper }\end{array}$ & 1990 & $1987-89$ & 1927 NAD & $\begin{array}{l}\text { ft, MSL } \\
\text { NGVD29 }\end{array}$ & $\begin{array}{l}\text { 1974 LWRP (97\% } \\
\text { duration discharge } \\
\text { 1954-73) }\end{array}$ \\
\hline Digital & 2004 & 2004 & 1983 NAD & ft NAVD 1988 & 1993 LWRP \\
\hline Digital & 2007 & $2005-06$ & 1983 NAD & ft NAVD 1988 & $\begin{array}{l}\text { 2005 LWRP (97\% } \\
\text { duration discharge } \\
1954-2005)\end{array}$ \\
\hline Digital & not published & 2008 & 1983 NAD & ft NAVD 1988 & 2005 LWRP \\
\hline Digital & not published & 2013 & 1983 NAD & ft NAVD 1988 & 2005 LWRP \\
\hline
\end{tabular}

Man-made activities along the Mississippi River have involved levee construction and constriction of the floodplain, construction of training dikes to control and direct channel flow, revetments to harden the riverbank and prevent excessive migration, and channel shortening or rectification of the Mississippi River from cutoffs to reduce flood stages. Subsidence, a naturally occurring process that lowers land areas, has influenced the LWRP near the Louisiana coast. This change has been especially pronounced during the past $100 \mathrm{yr}$ because of consolidation and compaction of the soft Holocene (less than 10,000 yr) deltaic sediments from urbanization; sea level rise; fluid withdrawal and groundwater pumping; oxidation and desiccation of surface soils, especially behind levees in urbanized areas; localized fault movements; and other causes. Thus, changes in the LWRP can occur from a variety of sources and in different parts of the LMV. Values for the LWRP provide an important tool to measure both short- and long-term geomorphic impacts in the watershed between decadal survey periods.

Helena Hydrographic Survey Sheet. The 1973-75 survey sheet (no. 81) for the Helena, AR, area on Plate 3 (Appendix C) and an enlarged portion shown in Figure 7 are used here as examples to highlight features of interest. The survey sheet identifies river mile locations from above the head-of-pass (i.e., river mile zero at Venice, LA). Attention is drawn to the position of the LWRP for both banks of the river (represented by a dashed line); the survey measurements along range lines across the river channel, which are expressed as elevation values; and the numeric elevation value for the LWRP as it changes with longitudinal distance upstream (see marker near river mile 664). Other noteworthy features identified on this sheet are the horizontal and vertical datums, the LWRP Year (1974 for this sheet and the corresponding period of record, 


\section{MRG\&P}

\section{Mississippi River Geomorphology \& Potamology Program}

which is usually denoted in the index sheet, not shown), and the presence of the MRC datum ticks to permit matching to older surveys if needed.

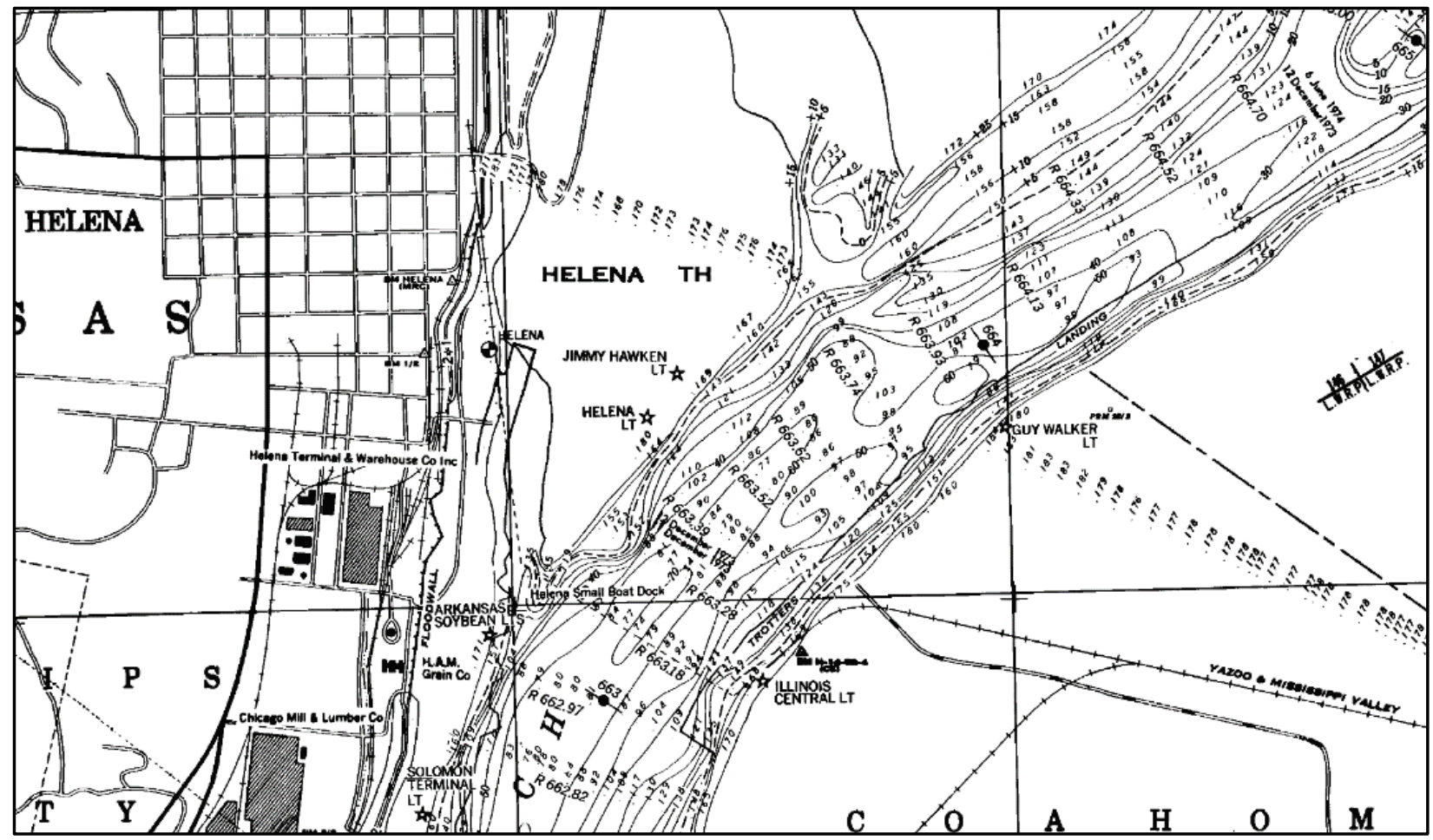

Figure 7. Portion of the 1973-75 hydrographic survey sheet from Helena, AR (see Plate 3 [Appendix C] for whole sheet), showing features of interest, benchmarks, survey range lines, LWRP (dashed lines), and cultural features. The value for LWRP changes near river mile 664.

Net Difference between NAVD88 and NGVD29. A graph of the net differences between NGVD29 and NAVD88 is presented in Figure 8 as a function of river mile for the 2005 LWRP for the Memphis District area of operations (river mile 595 to 954). Corpscon software was used to calculate the NGVD29 elevation from the NAVD88 elevation values (Minyard 2007).

The plot in Figure 8 identifies both negative and positive differences between the two survey datums along the longitudinal profile as a function of river mile. The maximum difference is generally less than $0.5 \mathrm{ft}$ for the entire profile from north to south, but appreciably lower for local areas such as Helena, AR, which has been used as an example area. As previously noted, the differences between NGVD29 and NAVD88 values are less than $0.3 \mathrm{ft}$.

The intended purpose for the plot in Figure 8 was to compare the magnitude of the elevation differences between NGVD29 and NAVD88 along the longitudinal profile in the Memphis District reach. The variation in Figure 8 is not valid for other areas outside of the Memphis area of operations in the LMV. The difference is probably much greater for coastal Louisiana with known subsidence issues occurring and variation across the coast because of geologic controls.

The longitudinal profile in Figure 8 identifies a lowering of the trend between river mile 890 to 940 , which is tentatively interpreted to be caused by the gravity component 
used for the NAVD88 geoid. The pronounced low in the upper part of the plot corresponds to the reach of river between New Madrid, MO, and below the confluence of the Ohio and Mississippi Rivers. This reach is part of the New Madrid Rift Zone, which is flanked by buried igneous plutons, the Missouri batholith, and measurable gravity anomalies and lows in the rift zone (Hildenbrand and Hendricks 1995).

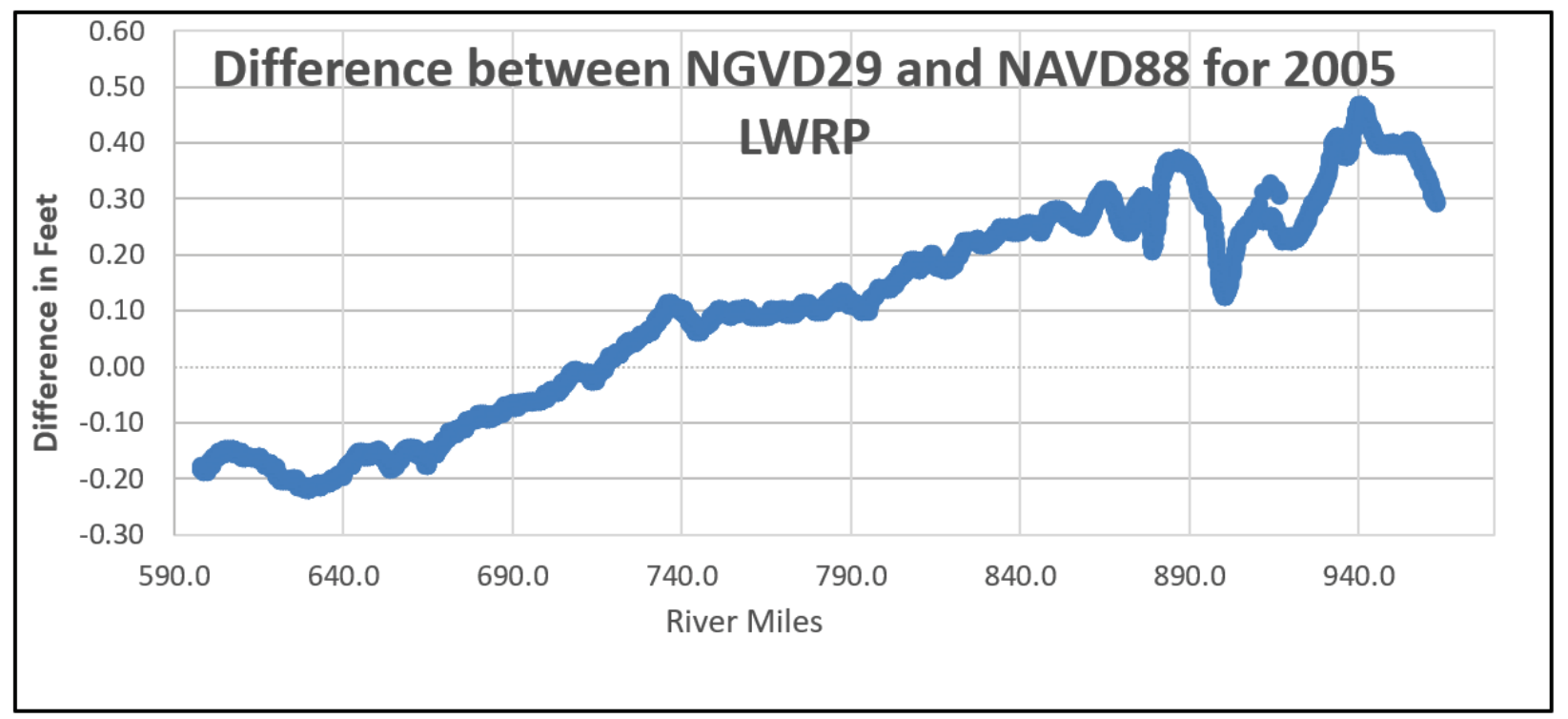

Figure 8. Difference between NGVD29 and NAVD88 as a function of river mile above head-of-pass. Values calculated using CORPSCON (Minyard 2007).

SUMMARY: This report has examined the different horizontal and vertical datums used by the MRC in the LMV. Horizontal datums used in the LMV have involved the MRC datum, NAD27, and NAD83. Vertical datums in the LMV have involved Cairo datum, Memphis datum, MGL, MSL, NGVD29, and NAVD88. Differences in these datums are examined using the Memphis, TN, to Helena, AR, reach as an example of these differences. The net vertical difference between NGVD29 and NAVD88 between river mile 595 to river mile 954 is less than $0.5 \mathrm{ft}$ along the broader reach but locally is less than $0.3 \mathrm{ft}$. Methods to convert between NGVD29 and NAVD88 elevation values have been presented along with online resources for acquiring benchmark data that are presented on historic hydrographic survey sheets. 


\section{REFERENCES}

Biedenharn, D. S., M. A. Allison, C. D. Little, C. R. Thorne, and C. C Watson. 2017. Large-Scale Geomorphic Change in the Mississippi River from St Louis, MO, to Donaldsonville, LA, as Revealed by Specific Gage Records. MRG\&P Report No. 10. Vicksburg, MS: US Army Engineer Research and Development Center. http://dx.doi.org/10.21079/11681/22744

Camillo, C. A., and M. T. Pearcy. 2004. Upon Their Shoulders: A History of the Mississippi River Commission from Its Inception through the Advent of the Modern Mississippi River and Tributaries Project. Vicksburg, MS: Mississippi River Commission. https://usace.contentdm.oclc.org/digital/collection/p16021coll4/id/154

Elliot, D. O., 1932. The Improvement of the Lower Mississippi River for Flood Control and Navigation. Three volumes. Vicksburg, MS: US Army Engineer Waterways Experiment Station.

Federal Register. 1973. "Notices.” National Vertical Control Net, Proposed Action 38(94): 12840. Washington, DC: Office of the Federal Register, National Archives and Records Service. https://www.govinfo.gov/content/pkg/FR-1973-05-16/pdf/FR-1973-05-16.pdf

Hildenbrand, T. G., and J. D. Hendricks. 1995. Geophysical Setting of the Reelfoot Rift and Relations between Rift Structures, and the New Madrid Seismic Zone. US Geological Survey Professional Paper 1538-E. Washington, DC: US Government Printing Office. https://doi.org/10.3133/pp1538E

Minyard T. L. 2007. Revision of the Low Water Reference Plane (LWRP). Memorandum for Commander, Mississippi Valley Division, 10 January 2007. Memphis, TN: US Engineer District, Memphis.

MRC (Mississippi River Commission). 1880. Survey of the Mississippi River. Chart No. 27. Vicksburg, MS: Mississippi River Commission. https://digital.library.illinois.edu/items/908c1cd0-82d4-0134-1f08$\underline{0050569601 c a-2}$

1915. Survey of the Mississippi River. Chart No. 26, Vicksburg, MS. Mississippi River Commission. https://digital.library.illinois.edu/items/908c1cd0-82d4-0134-1f08-0050569601ca-2

1929. Descriptions, Elevations, and Geodetic Positions of Permanent Marks Survery Mississippi River. Vicksburg, MS: Mississippi River Commission.

https://books.googleusercontent.com/books/content? req=AKW5QacGKphE1YKvz1lFqcObW4FlN1Xh4xhc rbW6WS F3pip xJZDMGAZaFiidNTdg-

WGBuE9xm6eUFNVKGDHXLUCYhtuGgppdYFgNAV0r9kFtFBAsb3lHJEOMmToxvjQktMFJYJ1J4Enc7s HPLuZMYev8pIGBwri-k-EbgREPVCA6DhOzXviFXnG y-VkPBY94kqka5NxR-LFJRpkXpiDT FLIH0vCMaPO3qcBdP8EB1lloY5PAWOPUBYrPxNBF6Nx90ikmAKhgXCLFDHwCRjmw6ScQjU rQx RQpyIq6dbbfbYHD870Ew.

NOAA (National Oceanic and Atmospheric Administration). 2014. Vertical Datum Transformation, Integrating America's Elevation Data, Estimation of Vertical Uncertainties in VDatum. https://vdatum.noaa.gov/

2020. National Geodetic Survey Data Explorer. https://geodesy.noaa.gov/NGSDataExplorer/.

Pearson, C., and D. Mick. 2007. Legacy Height Datums on the Mississippi and Illinois River. National Geodetic Survey, Publications Library, National Oceanic and Atmospheric Administration.

https://geodesy.noaa.gov/PUBS_LIB/Miss_ht\%20datums_ACSM_v3.pdf.

USACE (US Army Corps of Engineers). 1951. Mississippi River Levee and River Photocharts. 1948-49, Cairo, Illinois, to Arkansas River, scale 1:20,000. Memphis, TN: US Army Engineer District, Memphis.

1964. Mississippi River Hydrographic Survey. 1961-1963, Cairo, Illinois, to Mouth of White River, Arkansas, Mile 595 to Mile 954. Scale 1:20,000. Memphis, TN: US Army Engineer District, Memphis. 


\section{MRG\&P \\ Mississippi River Geomorphology \& Potamology Program}

1976. Mississippi River Hydrographic Survey. 1973-1975, Cairo, Illinois, to Mouth of White River, Arkansas, Mile 595 to Mile 954 AHP. Scale 1:20,000. Memphis, TN: US Army Engineer District, Memphis.

1990. Mississippi River Hydrographic Survey. 1987-1989, Cairo, Illinois, to Mouth of White River, Arkansas, Mile 595 to Mile 954. Scale 1:20,000. Memphis, TN: US Army Engineer District, Memphis.

2004. CORPSCON Version 6.0. Technical Documentation and Operating Instructions. US Army Corps of Engineers Army Geospatial Center Website. Alexandria, VA. https://www.agc.army.mil/What-wedo/Corpscon/

2010. Standards and Procedures for Referencing Project Elevation Grades to Nationwide Vertical Datums. EM-1110-2-6056. Washington, DC: Department of the Army, US Army Corps of Engineers. https://www.publications.usace.army.mil/Portals/76/Publications/EngineerManuals/EM 1110-2-6056.pdf

USCGS (US Coast and Geodetic Survey). 1914. Fourth General Adjustment of the Precise Level Net in the United States and the Resulting Standard Elevations. Special Publication 18. Washington, DC: US Geological Survey.

USGS (US Geological Survey). 1916a. Spirit Leveling in Arkansas, 1896 to 1915 Inclusive. Bulletin 636. Washington, DC: US Geological Survey. https://doi.org/10.3133/b636

1916b. Spirit Leveling in Louisiana, 1903 to 1915 Inclusive. Bulletin 634. Washington, DC: US Geological Survey. https://doi.org/10.3133/b634

1916c. Spirit Leveling in Mississippi, 1901 to 1915 Inclusive. Bulletin 639. Washington, DC: US Geological Survey. https://doi.org/10.3133/b639

Zilkoski, D. B., and G. M. Young. 1985. "North American Vertical Datum (NAVD) Update." Proceedings of the U.S. Army Corps of Engineers Surveying Conference Held at Jacksonville, Florida on 4-8 February 1985. Vicksburg, MS: US Army Engineer Waterways Experiment Station. https://apps.dtic.mil/sti/pdfs/ADA164678.pdf 